\title{
Relationships between urinary biomarkers of phytoestrogens, phthalates, phenols, and pubertal stages in girls
}

REVIEW

\author{
Tandra R Chakraborty' \\ Eilliut Alicea' \\ Sanjoy Chakraborty ${ }^{2}$ \\ 'Department of Biology, Adelphi \\ University, One South Avenue, Garden \\ City; ${ }^{2}$ Department of Biological \\ Sciences, New York City College of \\ Technology, New York, NY, USA
}

This article was published in the following Dove Press journal:

Adolescent Health, Medicine and Therapeutics

5 January 2012

Number of times this article has been viewed

\begin{abstract}
Phytoestrogens, phthalates, and phenols are estrogen-disrupting chemicals that have a pronounced effect at puberty. They are exogenous chemicals that are either plant-derived or man-made, and can alter the functions of the endocrine system and cause various health defects by interfering with the synthesis, metabolism, binding, or cellular responses of natural estrogens. Phytoestrogens, phthalates, and phenols are some of the potent estrogens detectable in urine. Phytoestrogens are plant-derived xenestrogens found in a wide variety of food products, like soy-based food, beverages, several fruits, and vegetables. Exposure to phytoestrogens can delay breast development and further lead to precocious puberty. The effect of phytoestrogens is mediated through estrogen receptors $\alpha$ and $\beta$ or by binding with early immediate genes, such as jun and fos. Phthalates are multifunctional synthetic chemicals used in plastics, polyvinyl chloride products, cosmetics, hair spray, and children's toys. Phthalates have been shown to cause defeminization, thelarche, precocious puberty, and an increase in breast and pubic hair in pubertal girls. However, reports are also available that show no association of phthalates with precocious puberty in girls. Phthalates can act through a receptor-mediated signaling pathway or affect the production of luteinizing hormone and follicle-stimulating hormone that has a direct effect on estrogen formation. Phenols like bisphenol A are industrial chemicals used mainly in the manufacture of polycarbonates and plastic materials. Bisphenol A has been shown to cause precocious puberty and earlier menarche in pubertal girls. Reports suggest that the neurotoxic effect of bisphenol A can be mediated either by competing with estradiol for binding with estrogen receptors or via the ERK/NK-kappa or ERR $\gamma$ pathway. This review demonstrates the effects of phytoestrogens, phthalates, and phenols on the development of girls during puberty.
\end{abstract}

Keywords: phytoestrogens, phenols, phthalates, estrogen, puberty

\section{Introduction}

Recent reports have shown that the onset of puberty in girls is much earlier than in the past. This may be due to direct or indirect exposure to many hormonally active agents that are widely available in the environment. ${ }^{1}$ These agents are known as endocrine-disrupting chemicals (EDCs). EDCs are present in pesticides, textiles, flame retardants, plastics, fragrances, detergents, lotions, paints, toiletries, food, and other products. ${ }^{2,3}$ The relationship between exposure to these EDCs and their effect on sexual development in girls was studied by observing metabolite content in various urine samples of prepubertal girls. ${ }^{4,5}$ The three most potent urinary biomarkers of EDC are phytoestrogens, phthalates, and phenols, that are estrogenic and affect the human body. It has been reported that, because EDCs are used in everyday life and are easily available, the effect of these environmentally active reagents is most pronounced during puberty. ${ }^{6}$

Correspondence: Tandra R Chakraborty Department of Biology, Adelphi University, One South Avenue, Garden City, New York, NY, USA

Tel + I 5168774202

Fax + I 5168774209

Email chakraborty@adelphi.edu 


\section{Hypothalamus-pituitary-gonadal axis and puberty}

The onset of puberty in girls is mainly governed by increased levels of hypothalamic gonadotropin-releasing hormone. ${ }^{7}$ Gonadotropin-releasing hormone triggers the secretion of luteinizing hormone and follicle-stimulating hormone from the anterior pituitary gland, which in turn causes the ovaries to respond and secrete estradiol (Figure 1). Estradiol then causes differential genetic expression via activation of nuclear estrogen receptors $\alpha$ and $\beta$ (ER $\alpha$ and $E R \beta)$ or a third receptor (either a plasma membrane-bound receptor or a cytoplasmic receptor). ${ }^{8}$ This results in secondary sexual characteristics and eventually the beginning of menses. ${ }^{9}$ The hypothalamic-pituitary-gonadal axis increases in activity during puberty but remains functional at all stages throughout life.

In 1969, James Tanner ${ }^{10}$ defined a scale based on the physical characteristics and development pattern in children,

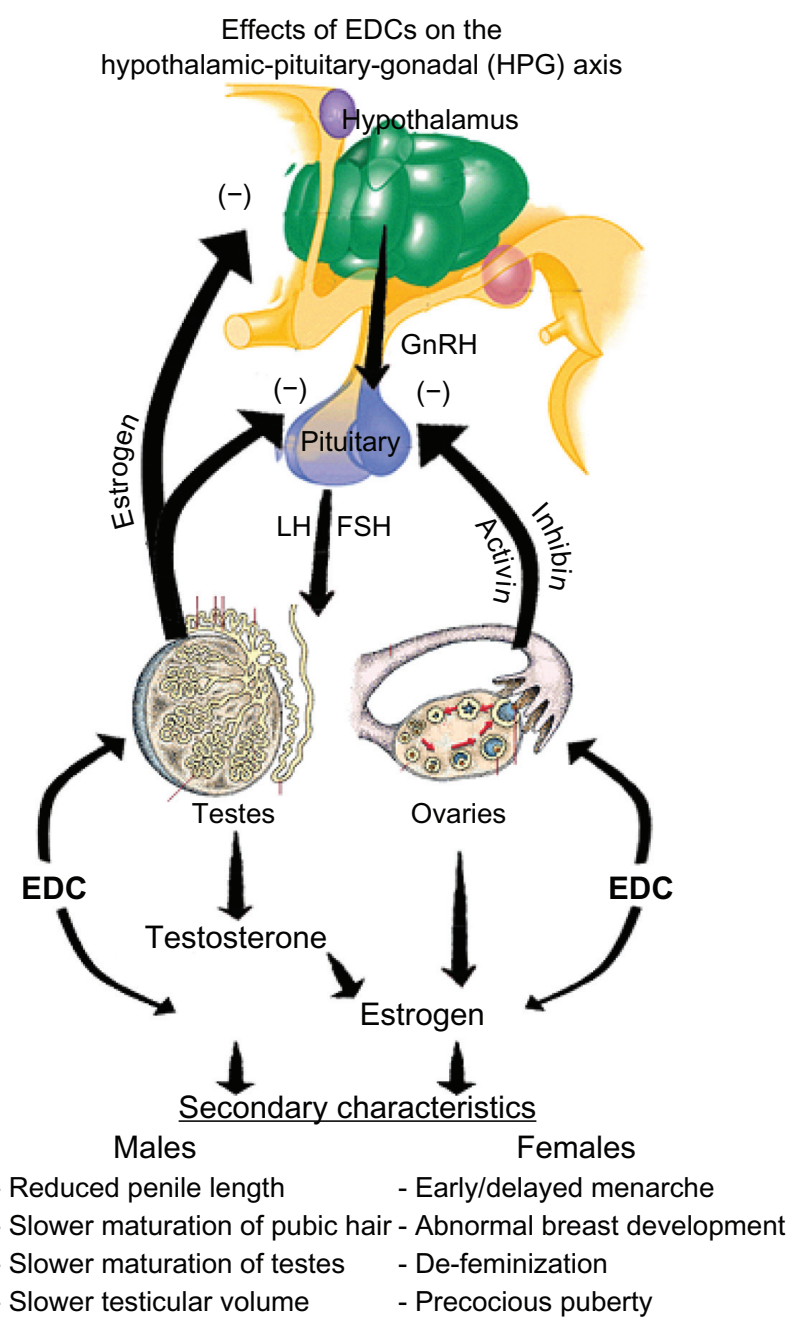

Figure I Effects of EDCs on the hypothalamic-pituitary-gondal (HPG) axis. adolescents, and adults (Table 1). The scale, when used for females, is based on primary and secondary sex characteristics, like breast size and pubic hair development. If a girl is found to have Tanner stage 2 or higher breast development (B2+), pubic hair development ( $\mathrm{PH} 2+$ ), beginning of menses, or axillary hair stage 2 or higher (axillary hair development is not described in Tanner staging; in the cited study stage 1 is absence of axillary hair, stage 2 is sparse, and stage 3 is mature), she is considered to be undergoing puberty. ${ }^{11}$ Tanner staging has for the most part been the norm for visual pubertal staging of girls.

\section{Estrogen and puberty}

Estrogen, a primary female sex hormone secreted mainly from the ovaries, is crucial for the sexual differentiation that takes place in the prenatal as well as the pubertal stage. Estradiol levels have shown to affect bone and brain maturation in both girls and boys. It also has a remarkable effect on breast development in girls during puberty. The timing of the growth spurt in pubertal girls is also related to estrogen. Studies have shown that male and female individuals with mutations of estrogen receptors show incomplete linear epiphyseal growth, normal skeletal proportions, and lower bone mineralization. Estrogen represses growth by closing the epiphyses in puberty. ${ }^{7}$ In both males and females, estrogen continues to assist maturation of sexual characteristics even after puberty. ${ }^{9}$

\section{Establishing a trend}

In the middle ages, pubertal development occurred at around 14 years of age. In the 1800 s, pubertal changes were seen to begin at around 17 years (Table 2). ${ }^{12}$ Evidently, before the last century, scientific standards for measuring pubertal development were not as strong as they are now. A pattern of decreasing age at onset of thelarche, pubarche, and menarche is seen in the US and Europe ${ }^{1}$ (Figure 2A and B). As of 1997, in the US, the average age of B2+ attainment for AfricanAmerican girls was 8.87 years and for Caucasian girls was 9.96 years. African-American girls experienced menarche at 12.16 years, and Caucasians at 12.88 years. ${ }^{11,13}$ In 2002 , another study indicated that African-American girls in the US started menses at 12.1 years, Caucasian girls at 12.7 years, and Mexican girls at 12.2 years. It also indicated that $49.4 \%$ of African-American girls showed breast development at 9 years of age compared with $15.8 \%$ for Caucasian girls and $24.5 \%$ for Mexican girls. ${ }^{14}$ It was concluded that the mean age of onset of puberty has been decreasing for decades (Figure 2A and B). ${ }^{1,11,14,15}$ By analyzing US data, a panel 
Table I Tanner stages of pubic hair and breast rating ${ }^{10}$

\begin{tabular}{|c|c|c|c|}
\hline & Age (years) & Pubic hair & Breast \\
\hline Tanner I & $<10$ & No pubic hair & $\begin{array}{l}\text { No glandular tissue, areola follows the skin contours } \\
\text { of the chest, elevation of papilla only }\end{array}$ \\
\hline Tanner II & $10-11.5$ & $\begin{array}{l}\text { Small amount of long, pigmented, downy hair, } \\
\text { straight or slightly curled hair along the labia majora }\end{array}$ & $\begin{array}{l}\text { Breast bud forms with a small area of surrounding } \\
\text { glandular tissue, elevation of breast and papilla, } \\
\text { areola begins to increase in diameter }\end{array}$ \\
\hline Tanner III & $11.5-13$ & $\begin{array}{l}\text { Hair becomes darker, rough and curly. } \\
\text { Some hair is also found over the junction of the pubis }\end{array}$ & $\begin{array}{l}\text { Breast begins to become more elevated and extends } \\
\text { beyond the borders of the areola, which takes the } \\
\text { shape of the breast }\end{array}$ \\
\hline Tanner IV & $13-15$ & $\begin{array}{l}\text { Adult like hair quality in a small and limited area. } \\
\text { There is sparing hair in the medial thighs }\end{array}$ & $\begin{array}{l}\text { Increased breast size and elevation, areola } \\
\text { and papilla form a secondary mound projecting } \\
\text { above of the level of the breast }\end{array}$ \\
\hline Tanner V & $15+$ & $\begin{array}{l}\text { Adult hair quality which extends to medial surface } \\
\text { of the thighs in the shape of an inverse triangle }\end{array}$ & $\begin{array}{l}\text { Breast reaches adult final size, areola regresses } \\
\text { to the general contour of the breast }\end{array}$ \\
\hline
\end{tabular}

concluded that there was a notable shift toward earlier ages for onset of thelarche and menarche between 1940 and 1994, and that it varied according to race/ethnicity. ${ }^{16}$ This may be a result of industrialization, an occurrence that has led to a precipitous increase in human exposure to plastics, building materials, pharmaceuticals, fertilizers, pesticides, hormones, and a myriad other things produced in high quantities during an era of synthetic industry.

\section{Endocrine-disrupting chemicals}

EDCs are exogenous substances that can be of plant, animal, or man-made origin. They are structurally and functionally similar to hormones and have the capacity to interfere with hormone receptor binding by blocking or mimicking hormone signaling pathways through their receptors. In 2005, the US Environmental Protection Agency discovered that less than $7 \%$ of 3000 chemicals produced at more than 1 million lbs per year did not have the complete set of six basic toxicity tests and that $43 \%$ underwent none of the six basic tests (acute toxicity, chronic toxicity, developmental and reproductive toxicity, mutagenicity, ecotoxicity, and environmental fate). ${ }^{2}$ Any number of these chemicals can be considered as EDC if they disrupt hormonal pathways. Most of these chemicals are estrogenic or antiandrogenic chemicals. They have a wide range of influence in animals as well as in humans. ${ }^{9,16}$

To detect the presence of EDCs in an organism, their unique metabolites are looked for in tissue and urine samples. Various studies are conducted to determine which metabolites can be considered as accurate biomarkers. ${ }^{17}$ Urinary biomarkers are particularly useful in identifying the presence of EDCs due to the relative ease of detecting their metabolites in urine. Because urine has a higher concentration of polar metabolites than other testable samples and is easy to collect, it is considered a good source for detection. ${ }^{4}$ Some of the potent synthetic estrogens detectable in urine are phytoestrogens, phthalates,

Table 2 Changes in pubertal age with race and ethnicity ${ }^{12}$

\begin{tabular}{|c|c|c|c|c|c|}
\hline Race/ethnicity & $\begin{array}{l}\text { Avg. age } \\
\text { at menarche }\end{array}$ & $\begin{array}{l}\text { Avg. age } \\
\text { at breast stage } 2+\end{array}$ & $\begin{array}{l}\text { Median age } \\
\text { at menarche }\end{array}$ & $\begin{array}{l}\text { Median age } \\
\text { at breast stage } 2+\end{array}$ & Year of publication \\
\hline \multicolumn{6}{|l|}{ US } \\
\hline African-American & 12.16 & 8.87 & & & 1997 \\
\hline Caucasian & 12.88 & 9.96 & & & 1997 \\
\hline NHANESIII & & & 12.5 & 9.7 & 2001 \\
\hline \multicolumn{6}{|l|}{ Europe } \\
\hline Netherlands & & 10.5 & & & 1985 \\
\hline England & & 11.2 & & & 1970 \\
\hline Spain & $12.9 \pm 0.2$ & & & & 2000 \\
\hline Sweden & & & 13.0 & & 1986 \\
\hline Germany & 13.30 & & & & 1984 \\
\hline Turkey & $13.28 \pm 1.09$ & & & & 1996 \\
\hline Overall & $12.5-13.1$ & & & & 1998 \\
\hline \multicolumn{6}{|l|}{ Asia } \\
\hline India & & & $12.8-14.4$ & & 1965 \\
\hline
\end{tabular}

Note: The year of publication refers to the studies done in different counties over the past years on the effect of EDC on puberty. The year designates how far back we have gone back or how recent these data are.

Abbreviations: EDC, Endocrine-disrupting chemicals; NHANESIII, National Health and Nutrition Examination survey the third - I99I-1994. 

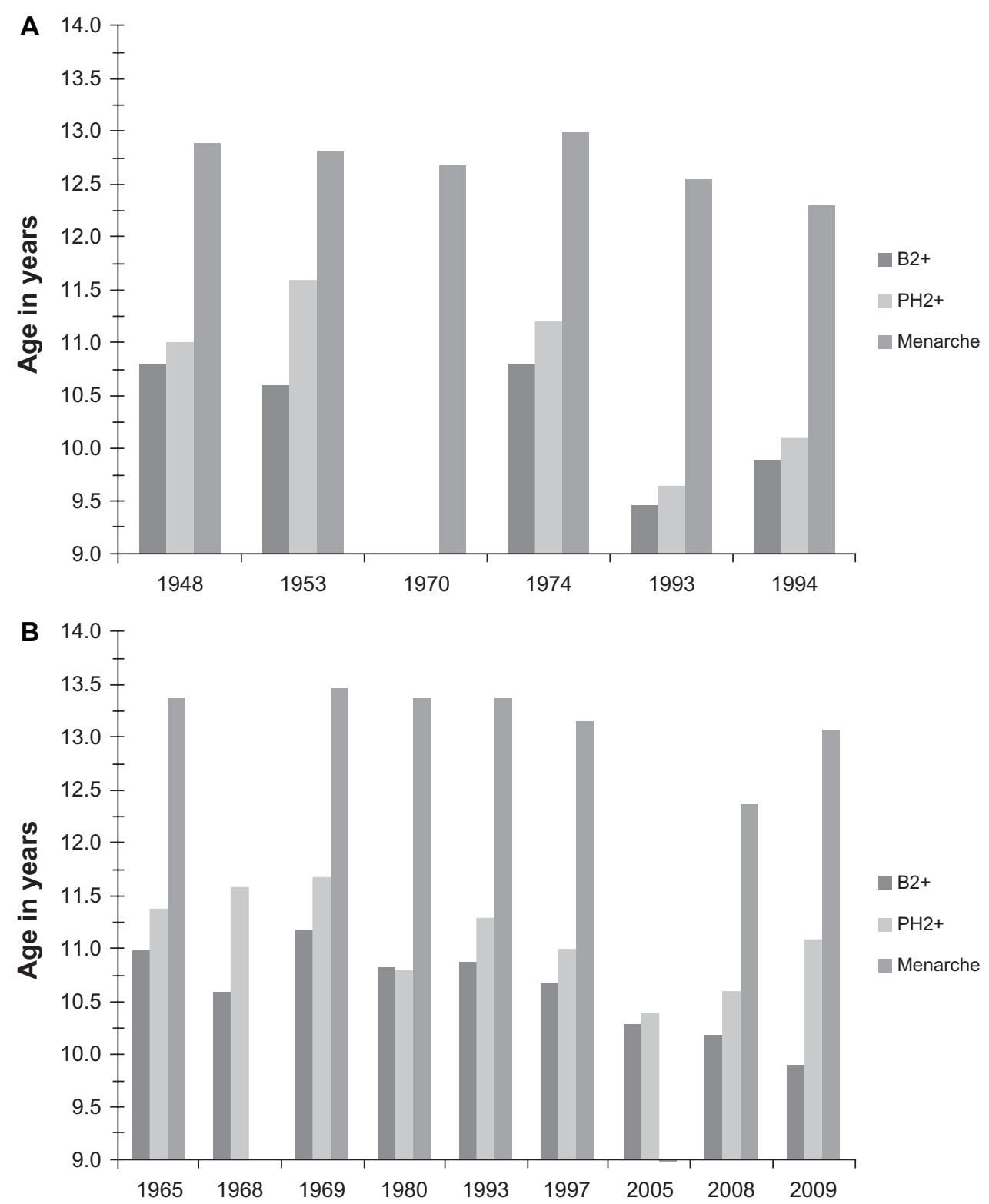

Figure 2 (A) Average ages of girls at B2+, PH2+, and menarche in US from 1948-1994.' (B) Average ages of girls at B2+, PH2+, and menarche in Europe from 1965-2009.'

phenols, polychlorinated biphenyls, polybrominated biphenyls, and DDT. ${ }^{9}$ Of these, the highest priority urinary exposure biomarkers identified by the The Breast Cancer and Environment Research Centers consortium are phytoestrogens, phthalates, and phenols. These were selected because they had hormonal activity and can act as agonists or antagonists. ${ }^{18,19}$ If present in significantly high amounts, they have the potential to disrupt homeostasis,${ }^{20}$ and have adequate interindividual variability to be detected as markers. ${ }^{4}$

\section{Mechanism of EDC action}

EDCs interfere with hormonal pathways by mimicking a hormone, by blocking a hormone receptor, and by altering the production, metabolism, transportation, release, elimination, and the binding ability of endogenous hormones. ${ }^{16}$ EDCs can be estrogenic, antiestrogenic, antiandrogenic, cytokines, thyroid modulators, growth factor modulators, or hormone metabolism modulators. ${ }^{3}$ An EDC may bind to a membrane-bound receptor, a cytoplasmic receptor, and/ or a nuclear receptor. This in turn prompts differential gene expression. Common nuclear receptors that are targeted by EDCs include ER $\alpha$, ER $\beta$, the androgen receptor, aryl hydrocarbon receptor, progesterone receptor, glucocorticoid receptor, and pregnane-X-R. ${ }^{3}$

Estrogen-like EDCs have a molecular structure (or part of its structure) similar to that of estrogen and disrupt estrogenic 
pathways by altering the feedback mechanisms in central or peripheral tissues. Estrogen-like EDCs exert their effects on $\mathrm{ER} \alpha, \mathrm{ER} \beta$, and the aryl hydrocarbon receptor. Estrogen binds with the estrogen receptor, dimerizes, and interacts with DNA response elements and modulates the expression of specific target genes. Estrogen receptors may indirectly stimulate gene expression by activating other transcription factors instead, such as Sp1 or AP-1, or avert gene activating methods by activating cytoplasmic molecules, such as mitogen-activated protein kinase, to incite rapid signaling. ${ }^{8}$ The hydrocarbon structures and halide contents of estrogenlike EDCs may be a factor accounting for why they can bind to the two nuclear receptors, ER $\alpha$ and ER $\beta$. Not only do EDCs bind with estrogen receptors but they may have higher affinity for estrogen receptors than for endogenous estrogen. ${ }^{8,21}$ This further increases the risk to human health of EDC exposure.

Estrogen receptors have particularly high affinity for xenestrogens, even more than endogenous estrogen, because of the molecular nature of the ligand-binding pocket. Estrogen receptors have three domains, ie, A/B, C, and D/E. The $\mathrm{D} / \mathrm{E}$ domain is the ligand-binding domain. The $\mathrm{C}$ domain acts as the hinge region and the DNA binding domain. The receptive part of the estrogen receptor responds to an overall ring structure, which is a characteristic feature of estrogen and xenestrogens. ${ }^{8,9}$ The aryl hydrocarbon receptor is a transcription factor of the Per-ARNT-SIM (bHLH-PAS) helix-loop-helix super family. When a ligand binds to it, it transports itself to the nucleus of the cell and dimerizes with aryl hydrocarbon receptor nuclear translocator. The dimer then stimulates expression of genes involved in the metabolism of exogenous and some endogenous compounds. Aryl hydrocarbon receptor pathways, interestingly, are noted to be intertwined at times with estrogen receptor pathways and possibly act as an estrogen receptor regulator. ${ }^{8}$

\section{Precocious puberty}

In precocious puberty, the pubertal changes occur earlier than expected, ${ }^{22}$ ie, earlier appearance of secondary sex characteristics such as breast development, growth of pubic hair, and earlier menarche and thelarche. More precisely, if the thelarche occurs before 8 years of age or menarche before 9 years of age, the girl is considered to have precocious puberty. ${ }^{14}$ Puberty at an earlier age causes physiological changes like preparedness for sexual readiness and childbearing ability. Since pubertal girls are psychologically immature, they are prone to making wrong decisions which may negatively impact society. Changes in pubertal timing can also cause several physical and physiological diseases. Precocious puberty can also lead to early diagnosis of breast cancer ${ }^{23}$ and adult obesity. ${ }^{24}$ With early puberty, there is a risk of accelerated bone maturation and short height, behavioral disorders, and psychological problems.

Precocious puberty can be of two types, ie, peripheral precocious puberty and central precocious puberty. Peripheral precocious puberty results from sex steroid release by a process other than activation of the hypothalamic-pituitary-gonadal axis like ovaries, adrenal glands, and/or the pituitary gland. Central precocious puberty is pubertal development due to early stimulation of the hypothalamus to release gonadotropin-releasing hormone into the hypothalamicpituitary-gonadal axis. Peripheral precocious puberty has been associated with xenestrogens, while the association of central precocious puberty and xenestrogens remains uncertain. ${ }^{3}$ Premature thelarche can be the first sign of precocious puberty. Premature thelarche is isolated breast development without pubic or axillary hair development before 8 years of age. A higher level of follicle-stimulating hormone is seen in girls exhibiting premature thelarche. Another condition, known as exaggerated thelarche, involves precocious breast development without axial hair or pubic hair development, but with an increased overall growth rate and advanced bone development. ${ }^{25}$ Central precocious puberty occurs in girls 10 times more often than in boys. It is estimated that $10 \%-20 \%$ of girls show precocious puberty because of physical brain abnormalities. ${ }^{1}$

\section{Factors influencing precocious puberty}

Many factors have attributed to a decrease in the age of menarche, thelarche, and pubarche. A positive correlation between body mass index and onset of puberty is believed to contribute to the trend and to some of the racial/ethnic differences. Girls with a higher body mass index typically exhibit earlier onset of puberty. It has been observed that many African-American girls have a higher body mass index than Caucasian girls, which can contribute to racial/ ethnic differences in puberty. ${ }^{9}, 12,14$ Higher birth weight was seen to be correlated with earlier onset of puberty. ${ }^{9}$ Genetics also play a role in the onset of puberty. A Finnish study of 1928 twin boys and 2309 twin girls concluded that genetics accounted for $86 \%$ of differences in pubertal timing for boys and $82 \%$ for girls. ${ }^{16}$ Illness and physical injury particularly in the hypothalamus and endocrine functional areas can lead to earlier or delayed puberty in girls. ${ }^{9}$ Organic compounds containing heavy metals and EDCs that can cause 
an indirect effect, such as triphenyltin, have been shown to delay puberty in higher concentrations or cause precocious puberty at smaller doses. It can delay puberty or trigger it by inhibiting enzymes or interfering with molecules involved in the hypothalamic-pituitary-gonadal axis. ${ }^{9,16}$

\section{Phytoestrogens}

Phytoestrogens are plant-derived xenestrogens found in a wide variety of food products. They belong to the polyphenolic group of compounds. There are three major classes of phytoestrogens. These are isoflavones (genistein, diadzein, biochanin), ${ }^{26}$ lignans (enterolactone, enterodiol), ${ }^{27}$ and coumestans. ${ }^{28}$ The two major chemical classes of phytoestrogens found in the human diet are isoflavones and lignans. Phytoestrogens are found mostly in citrus fruit, cherries, berries, apples, grapes, celery, capsicum, broccoli, onions, tomatoes, red wine, flaxseeds, grains, nuts, chocolate, green tea, soya bean, legumes, clover, alfalfa, and spinach. Diadzein and genistein are the two best known isoflavones, and are found in soy-based food and beverages. Phytoestrogens have long been associated with a reduction in risk of osteoporosis, heart disease, breast cancer, and menopausal symptoms.

Recently, phytoestrogens have been found to affect the timing of puberty, which can disrupt the ability to produce viable fertile offspring, sex-specific behavior, and fertility in animals. ${ }^{29-31}$ Genistein when given to CD1 mice in the neonatal period at low doses $(0.5$ and $5.0 \mathrm{mg} / \mathrm{kg})$ has been shown to advance puberty and mammary gland morphogenesis. When given at high doses $(50 \mathrm{mg} / \mathrm{kg})$, genistein causes delayed mammary gland morphogenesis. Further, genistein at $0.5 \mathrm{mg} / \mathrm{kg}$ causes increased ovulation when compared with controls, and at $50 \mathrm{mg} / \mathrm{kg}$ decreases ovulation. Fortes et $\mathrm{al}^{32}$ reported a case study of precocious thelarche occurring very early in a girl due to excessive intake of phytoestrogens in the form of soy. When the soy intake was reduced, the girl showed a bone and chronological age for puberty development similar to that of girls on a regular diet. ${ }^{32}$ Exposure to phytoestrogens in different regions of the US was studied in 1151 girls using urinary biomarkers. Among the three EDCs (phytoestrogens, phthalates, and phenols) studied, phytoestrogens as a group were present in the highest concentrations. All six phytoestrogens (enterolactone, genistein, diadzein, equol, enterodiol, $O$-DMA) were detected in more than $98 \%$ of the samples collected. The highest concentration among the six phytoestrogens was for enterolactone. Exposure to different phytoestrogens varied according to race/ethnicity, site, and body mass index. Enterolactone exposure was higher in girls with a lower body mass index than in those with a higher body mass index. Increased exposure to diadzein and genistein delayed breast development in pubertal girls. ${ }^{4}$ Another study done in 227 girls showed that when isoflavone was added to the diet of healthy white children, breast development (Tanner 2) was delayed by 0.7 years compared with girls having a low isoflavone diet. ${ }^{26}$

Further, the same research group reported an association between urinary isoflavone and puberty. A study of 192 healthy 9-year-old girls in inner New York City showed that intake of dietary phytoestrogens was not significantly related to breast development. ${ }^{33}$ Urinary phytoestrogen biomarker concentrations were lower in girls with breast development than in those with no breast development. Breast development had a significant relationship with body mass index. Because adipose tissue is a source of peripubertal hormones, it is important to take body mass index into consideration. There was a delay in breast development in girls with body mass index below the median and high levels of urinary diadzein, and girls with a higher or median body mass index showed a similar effect on exposure to genistein. The effect of urinary enterolactone was seen only in girls with high body mass index. Girls with high urinary enterolactone had delayed breast development, but no effect on development of pubic hair was noted on EDC exposure. ${ }^{34}$

\section{Mechanism}

Phytoestrogens have been shown to inhibit pathways of cell growth and proliferation, and to affect multiple organ systems. ${ }^{35}$ Recently, phytoestrogens have been found to have effects similar to those of man-made EDCs. When phytoestrogens are ingested, they can be metabolized by gut flora (intestinal bacteria) in the large intestine into the mammalian lignans, enterodiol and enterolactone. These metabolic products are then excreted directly in the feces after being absorbed from the gut or reabsorbed from the intestine. They are eventually excreted in a conjugated form ${ }^{36}$ and can be detected in urine.

The structural similarities between the phenolic ring of phytoestrogens and estrogen enable phytoestrogens to bind to estrogen receptors. Phytoestrogens have been found to bind to both $\operatorname{ER} \alpha$ and $\operatorname{ER} \beta$ and to activate estrogen receptor-dependent gene transcription through both subtypes, have relatively higher binding affinity for $\mathrm{ER} \alpha$ than for $\mathrm{ER} \beta,{ }^{37,38}$ and to bind with early immediate genes, such as jun and fos. ${ }^{39}$ Another hormone which is of importance is progesterone. Progesterone is important for differentiation of the mammary gland. The mammary gland is rudimentary at 
birth and progresses with puberty with the influx of estrogen and progesterone. It has been speculated that phytoestrogens block progesterone action in a significant manner. The effect of phytoestrogens on mammary gland development could involve blocking of the progesterone receptor or the combined effect of estrogen and progesterone. ${ }^{40}$

\section{Phthalates}

Phthalates are multifunctional synthetic chemicals used in a variety of consumer products. They are oily, colorless, odorless liquids that do not evaporate readily. Higher molecular weight phthalates, ie, di-(2-ethylhexyl) phthalates (DEHP), di-isodecyl phthalate, and di-isononyl phthalate, are produced in high volumes for use in construction materials, clothing, children's toys, and household furnishings. Low molecular weight phthalates, like di- $n$-butyl phthalate, diethyl phthalate, and dimethyl phthalate, are mainly used as solvents and in adhesives, waxes, inks, cosmetics, insecticides, and pharmaceuticals. They are found in the environment in high and low molecular weight forms. The US and Canada have now banned use of DEHP in the making of pacifiers for children, but it is still used to make soft-squeeze toys. In the medical industry, use of phthalates continues in tubing, blood bags, dialysis equipment, and disposable medical examination gloves.

Humans are exposed to phthalates on a daily basis due to their widespread production and use. Phthalates have been shown to cause defeminization, thelarche, and early secondary breast development in pubertal girls. ${ }^{41}$ Reports have shown that phthalates can cause toxicity to the fetus and have a significant effect on development and reproduction. Exposure to phthalates causes females to grow more rapidly and causes onset of puberty at an earlier age, and the overall height at adulthood of these females may be shorter than others. ${ }^{14}$ Studies done in China showed that girls with precocious puberty had higher serum DEHP levels than girls with onset of puberty at the normal age. These girls had a significantly larger ovarian and uterus size than a control group. ${ }^{42}$ In Puerto Rico, girls aged 8 months to 8 years were shown to have thelarche on serum exposure to phthalates. ${ }^{41}$ However, examination of urinary biomarkers for phthalates in US girls showed no difference between girls with precocious puberty and a control group. ${ }^{43}$ Studies in 1151 girls aged 6-8 years from New York City, greater Cincinnati, Ohio, and northern California showed that higher intake of low molecular weight phthalates increased both breast and pubic hair development. On the other hand, an inverse relationship was found with high molecular weight phthalates and pubic hair development. ${ }^{5}$ The differences in results reported by different research groups could be due to the different locations of the studies, ethnicity, age, or a cumulative effect of other EDCs.

\section{Mechanism}

Exposure to phthalates occurs via ingestion, inhalation, intravenous injection tubing and solutions, and skin absorption. When phthalates are leached from one product into another, they can have a direct and more drastic effect. Chemicals contained in these products are absorbed through the skin, and then enter the bloodstream. Upon reaching the intestine, diester phthalates are hydrolyzed into monoester phthalates. ${ }^{44}$ Short-branched phthalates (eg, diethyl phthalate and dimethyl phthalate) are excreted mainly in the urine as monoester phthalates, while the more long-branched phthalates (eg, DEHP) undergo further hydroxylation and oxidation before they are excreted in urine and feces. ${ }^{44}$ There have been several mechanisms cited for the action of phthalates on reproduction: they can act through a receptor-mediated signaling pathway to suppress estradiol production in the ovary leading to anovulation; they have also been shown to affect production of luteinizing hormone and folliclestimulating hormone which have a direct effect on estrogen formation; ${ }^{45}$ and by activation of peroxisome proliferationactivated receptors, causing decreased estradiol synthesis, and increased estradiol metabolism, causing suppressed estradiol levels. ${ }^{45}$

\section{Phenols}

Phenols are weakly acidic, water-soluble organic chemical compounds related to phenol. Phenols are industrial chemicals used mainly to manufacture polycarbonates and plastic materials. The more commonly studied phenols are bisphenol A and alkyl phenols. Other phenols that are thought to have EDC effects are benzophenone-3, 2,5-dichlorophenol, triclosan, and parabens. ${ }^{5,46,47}$ Phenols are commonly found in Tupperware ${ }^{\mathrm{TM}}$ products, baby bottles, polycarbonate bottles, food cans, microwave containers, dental sealants, medical products, and plastic tubing. ${ }^{9,33,47-49}$ Alkyl phenol ethoxylates are used as surfactants in detergents, disinfectants, surface cleaners, and pesticides. Tris(nonylphenol) phosphite is also used as a plasticizer. ${ }^{2,47}$ Parabens is used in preservatives and microbicides. It is typically found in jellies, syrups, baked goods, drinks, shampoos, deodorants, hairsprays, cosmetics, and pharmaceuticals. ${ }^{2}$ 1,4-dichlorobenzene, which is metabolized to 2,5-dichlorophenol, is found in deodorizers and mothballs. Benzophenone-3 is typically found in sunscreens. 
Triclosan acts as a microbicide and is likely to be found in a wide variety of consumer products. ${ }^{5,34}$

Other important routes for exposure to phenols include ingestion, dermal absorption, and inhalation. ${ }^{2,46,48,49}$ At high temperatures, polymers containing bisphenol $\mathrm{A}$ in canned foods, plastic containers, and polycarbonate bottles hydrolyze, allowing bisphenol A to leech out. ${ }^{47,49}$ It takes about 24 hours for bisphenol A to be excreted from the body, mainly in the form of a glucuronide conjugate. ${ }^{47,48}$ Because bisphenol A accumulates in the body, the full amount of bisphenol A intake may not correspond to urinary bisphenol A metabolite levels. ${ }^{2,46,47}$ Nonylphenol is thought to be excreted within 8 hours of ingestion, be metabolized to glucuronide, or sulfated and then excreted in urine. ${ }^{47,50}$

In animal models, it has been shown that prenatal alkyl phenol exposure causes increased or decreased birth weight in rodents. ${ }^{51,52}$ It was seen to affect the estrus cycle, pubertal onset, mammary gland development, brain sexual differentiation, and cell division by meiosis. ${ }^{47}$ The metabolite, 2,5-dichlorophenol, causes lower birth weight in rats. ${ }^{53}$ A pilot study completed in November 2006 examined urinary biomarkers in 90 peripubertal Asian, Black, Hispanic, and White girls to determine exposure to three chemical families, ie, phytoestrogens, phthalate, and phenols. Nine phenols were sampled. Phenols had the lowest concentrations of the three chemical families sampled. Three of the nine phenols (ie, bisphenol A, benzophenone-3, and 2,5-dichlorophenol) were detected in more than $94 \%$ of the samples collected. The highest concentration was for benzophenone-3. Benzophenone-3 levels were higher in Whites and 2,5-dichlorophenol levels were higher in Blacks. Benzophenone-3 was higher in samples collected in summer. In women, 2,5-dichlorophenol and benzophenone- 3 exposure has been associated with reduced or increased birth weight. 2,5-dichlorophenol seems to promote breast development in girls with high body mass index, but the relationship is nullified after stratifying for body mass index. Exposure to benzophenone-3 causes an increase in breast development in girls with a low body mass index and has an opposite effect in girls with high body mass index. ${ }^{5}$ Triclosan seems to have an inverse relationship with development of pubic hair. Of all the phenols identified so far, bisphenol $\mathrm{A}$ is produced in the highest quantities. It has been linked with liver damage, ${ }^{54,55}$ diabetes, and cardiovascular disease. ${ }^{56}$ In animals, bisphenol A can cause damage and malfunction of the reproductive organs, a decline in the quality of embryos, and increased cell proliferation in females. Bisphenol A has been shown to cause disruption of pubertal timing in female rats. Female rats exposed to $50 \mu \mathrm{g} / \mathrm{kg}$ of bisphenol A for first 4 days show an advanced pubertal timing, whereas higher doses delayed it. ${ }^{27} \mathrm{~A}$ similar trend has been observed in industrialized nations. Children aged 6-11 years have been shown to have the highest urinary concentrations of bisphenol A than any other age group studied. ${ }^{57}$ Bisphenol A was shown to cause precocious puberty in pubertal girls and an increase in genital abnormalities in boys. ${ }^{58}$ Minority populations in the US have shown delayed menarche when exposed to bisphenol A. Similar results have been reported in Europe, and in girls who are adopted and move from developing to industrialized countries. ${ }^{12}$ Studies have shown that postnatal exposure of rats to bisphenol A at low doses decreases basal luteinizing hormone secretion, alters the estrus cycle, increases gonadotropin-releasing hormone pulsatility, and at higher doses, causes precocious puberty and a persistent estrus phase. ${ }^{49}$ A study in 1151 girls aged 6-8 years from New York City, greater Cincinnati, Ohio, and northern California showed that benzophenone-3 increased breast development in girls with low body mass index and had an opposite effect in girls with high body mass index. Further, this study concluded that phenols were associated with pubertal timing. ${ }^{5}$

\section{Mechanism}

Phenols are well absorbed from the gastrointestinal tract and through the skin. They are metabolized to quinone-related reactive intermediates, which bind covalently to protein and are detoxified by conjugation with glutathione. Most of the absorbed phenol and its metabolites are excreted in the urine. There are differences in scientific opinion regarding the mechanism of action of phenols. Reports suggest that the neurotoxic effects of bisphenol A can be mediated either by competing with estradiol for binding with estrogen receptors ${ }^{59}$ or through the ERK/NK-kappa ${ }^{60} / E R R \gamma^{61}$ pathway, which is an indirect pathway of estrogen action through its membrane receptor. The actions of bisphenol A are less potent than those of estrogen, and act antagonistically on peroxidase activity in the presence of estrogen. ${ }^{62}$ Alkyl phenols also mimic estrogen, and are believed to act through other endocrine pathways as well. ${ }^{2}$ However, bisphenol A and alkyl phenols are less potent than estrogen itself. ${ }^{2}$

\section{Conclusion}

It appears that phytoestrogens, phthalates, and phenols all affect the timing of puberty, thelache, and menarche, leading to precocious puberty. Precocious puberty can result in diseases such as obesity, diabetes, and cancer, and has psychological consequences. Because EDCs are easily 
available and present in products that are used in day-to-day life, it is the social responsibility of all individuals to be aware of the consequences and educate their children about how to adapt to an earlier age of sexual maturity. Although there are many government-driven biomonitoring programs in progress, research should be focused not only on understanding the risks involved in exposure to these agents, but also on preventative strategies. Use of these compounds should be limited as far as possible. Future studies need to be conducted in order to reveal the exact actions of EDCs, how they may be removed or contained in our environment, and limit further health risks.

\section{Disclosure}

The authors report no conflicts of interest in this work.

\section{References}

1. Mouritsen A, Aksglaede L, Sorensen K, et al. Hypothesis: exposure to endocrine-disrupting chemicals may interfere with timing of puberty. Int J Androl. 2010;33(2):346-359.

2. Rudel RA, Perovich LJ. Endocrine disrupting chemicals in indoor and outdoor air. Atmos Environ. 2009;43(1):170-181.

3. Caserta D, Maranghi L, Mantovani A, Marci R, Maranghi F, Moscarini M. Impact of endocrine disruptor chemicals in gynaecology. Hum Reprod Update. 2008;14(1):59-72.

4. Wolff MS, Teitelbaum SL, Windham G, et al. Pilot study of urinary biomarkers of phytoestrogens, phthalates, and phenols in girls. Environ Health Perspect. 2007;115(1):116-121.

5. Wolff MS, Teitelbaum SL, Pinney SM, et al. Investigation of relationships between urinary biomarkers of phytoestrogens, phthalates, and phenols and pubertal stages in girls. Environ Health Perspect 2010;118(7):1039-1046.

6. Partsch CJ, Sippell WG. Pathogenesis and epidemiology of precocious puberty. Effects of exogenous oestrogens. Hum Reprod Update. 2001;7(3):292-302.

7. Aksglaede L, Juul A, Leffers H, Skakkebaek NE, Andersson AM. The sensitivity of the child to sex steroids: possible impact of exogenous estrogens. Hum Reprod Update. 2006;12(4):341-349.

8. Swedenborg E, Ruegg J, Makela S, Pongratz I. Endocrine disruptive chemicals: mechanisms of action and involvement in metabolic disorders. J Mol Endocrinol. 2009;43(1):1-10.

9. Roy JR, Chakraborty S, Chakraborty TR. Estrogen-like endocrine disrupting chemicals affecting puberty in humans - a review. $\mathrm{Med} S \mathrm{Sci}$ Monit. 2009;15(6):RA137-RA145.

10. Marshall WA, Tanner JM. Variations in pattern of pubertal changes in girls. Arch Dis Child. 1969;44(235):291-303.

11. Herman-Giddens M, Slora E, Wasserman R, et al. Secondary sexual characteristics and menses in young girls seen in office practice: A study from the Pediatric Research in Office Settings network. Pediatrics. 1997;99:505-512.

12. Toppari J. Environmental endocrine disrupters and disorders of sexual differentiation. Semin Reprod Med. 2002;20(3):305-312.

13. Teilmann G, Juul A, Skakkebaek NE, Toppari J. Putative effects of endocrine disrupters on pubertal development in the human. Best Pract Res Clin Endocrinol Metab. 2002;16(1):105-121.

14. Cesario SK, Hughes LA. Precocious puberty: a comprehensive review of literature. J Obstet Gynecol Neonatal Nurs. 2007;36(3):263-274.

15. Toppari J, Kaleva M, Virtanen HE. Trends in the incidence of cryptorchidism and hypospadias, and methodological limitations of registrybased data. Hum Reprod Update. 2001;7(3):282-286.
16. Jacobson-Dickman E, Lee MM. The influence of endocrine disruptors on pubertal timing. Curr Opin Endocrinol Diabetes Obes. 2009;16(1): 25-30.

17. Coca SG, Parikh CR. Urinary biomarkers for acute kidney injury: perspectives on translation. Clin J Am Soc Nephrol. 2008;3(2): 481-490.

18. Fenton SE. Endocrine-disrupting compounds and mammary gland development: early exposure and later life consequences. Endocrinology. 2006;147(6 Suppl):S18-S24.

19. Rajapakse N, Silva E, Kortenkamp A. Combining xenoestrogens at levels below individual no-observed-effect concentrations dramatically enhances steroid hormone action. Environ Health Perspect. 2002; 110(9):917-921.

20. Centers for Disease Control and Prevention. National Report on Human exposure to Environmental Chemicals, Atlanta, GA. Available from: http://www.cdc.gov/exposurereport/. Accessed September 25, 2006.

21. Witorsch RJ. Endocrine disruptors: can biological effects and environmental risks be predicted? Regul Toxicol Pharmacol. 2002;36(1): 118-130.

22. Pigneur B, Trivin C, Brauner R. Idiopathic central precocious puberty in 28 boys. Med Sci Monit. 2008;14(1):CR10-CR14.

23. Hamilton AS, Mack TM. Puberty and genetic susceptibility to breast cancer in a case-control study in twins. $N$ Engl J Med. 2003;348(23): 2313-2322.

24. Biro FM. Body morphology and its impact on adolescent and pediatric gynecology, with a special emphasis on polycystic ovary syndrome. Curr Opin Obstet Gynecol. 2003;15(5):347-351.

25. Codner E, Cassorla F. Puberty and ovarian function in girls with type 1 diabetes mellitus. Horm Res. 2009;71(1):12-21.

26. Cheng G, Remer T, Prinz-Langenohl R, Blaszkewicz M, Degen GH, Buyken AE. Relation of isoflavones and fiber intake in childhood to the timing of puberty. Am J Clin Nutr. 2010;92(3):556-564.

27. Patisaul HB, Todd KL, Mickens JA, Adewale HB. Impact of neonatal exposure to the ER alpha agonist PPT, bisphenol-A or phytoestrogens on hypothalamic kisspeptin fiber density in male and female rats. Neurotoxicology. 2009;30(3):350-357.

28. Kurzer MS, Xu X. Dietary phytoestrogens. Anпи Rev Nutr. 1997;17: 353-381.

29. Bennetts HW, Underwood EJ. The oestrogenic effects of subterranean clover (Trifolium subterraneum); uterine maintenance in the ovariectomised ewe on clover grazing. Aust J Exp Biol Med Sci. 1951;29(4): 249-253.

30. Bennetts HW, Underwood EJ, Shier FL. A specific breeding problem of sheep on subterranean clover pastures in Western Australia. Br Vet J. 1946;102(11):348-352.

31. Adams NR. Detection of the effects of phytoestrogens on sheep and cattle. J Anim Sci. 1995;73(5):1509-1515.

32. Fortes EM, Malerba MI, Luchini PD, et al. High intake of phytoestrogens and precocious thelarche: case report with a possible correlation Arq Bras Endocrinol Metabol. 2007;51(3):500-503. Portuguese.

33. Wolff MS, Britton JA, Boguski L, et al. Environmental exposures and puberty in inner-city girls. Environ Res. 2008;107(3):393-400.

34. Wolff MS, Engel SM, Berkowitz GS, et al. Prenatal phenol and phthalate exposures and birth outcomes. Environ Health Perspect. 2008; 116(8):1092-1097.

35. Lurje G, Lenz HJ. EGFR signaling and drug discovery. Oncology. 2010;77(6):400-410.

36. Lampe JW. Isoflavonoid and lignan phytoestrogens as dietary biomarkers. J Nutr. 2003;133 Suppl 3:956S-964S.

37. Kuiper G, Shughrue P, Merchenthaler I, Gustafsson J. The estrogen receptor beta subtype: a novel mediator of estrogen action in neuroendocrine systems. Front Neuroendocrinol. 1998;19(4):253-286.

38. Pfitscher A, Reiter E, Jungbauer A. Receptor binding and transactivation activities of red clover isoflavones and their metabolites. $J$ Steroid Biochem Mol Biol. 2008;112(1-3):87-94.

39. Kushner PJ, Agard DA, Greene GL, et al. Estrogen receptor pathways to AP-1. J Steroid Biochem Mol Biol. 2000;74(5):311-317. 
40. Padilla-Banks E, Jefferson WN, Newbold RR. Neonatal exposure to the phytoestrogen genistein alters mammary gland growth and developmental programming of hormone receptor levels. Endocrinology. 2006;147(10):4871-4882.

41. Colon I, Caro D, Bourdony CJ, Rosario O. Identification of phthalate esters in the serum of young Puerto Rican girls with premature breast development. Environ Health Perspect. 2000;108(9):895-900.

42. Durmaz E, Ozmert EN, Erkekoglu P, et al. Plasma phthalate levels in pubertal gynecomastia. Pediatrics. 2010;125(1):e122-e129.

43. Lomenick JP, Calafat AM, Melguizo Castro MS, et al. Phthalate exposure and precocious puberty in females. J Pediatr. 2010;156(2):221-225.

44. Frederiksen H, Skakkebaek NE, Andersson AM. Metabolism of phthalates in humans. Mol Nutr Food Res. 2007;51(7):899-911.

45. Lovekamp-Swan T, Davis BJ. Mechanisms of phthalate ester toxicity in the female reproductive system. Environ Health Perspect. 2003;111(2):139-145.

46. You L, Zhu X, Shrubsole MJ, et al. Renal function, bisphenol A, and alkylphenols: results from the National Health and Nutrition Examination Survey (NHANES 2003-2006). Environ Health Perspect. 2010;119(4):527-533.

47. Calafat AM, Kuklenyik Z, Reidy JA, Caudill SP, Ekong J, Needham LL. Urinary concentrations of bisphenol A and 4-nonylphenol in a human reference population. Environ Health Perspect. 2005;113(4):391-395.

48. Lakind JS, Naiman DQ. Daily intake of bisphenol A and potential sources of exposure: 2005-2006 National Health and Nutrition Examination Survey. J Expo Sci Environ Epidemiol. 2010;21(3):272-279.

49. Fernandez M, Bianchi M, Lux-Lantos V, Libertun C. Neonatal exposure to bisphenol A alters reproductive parameters and gonadotropin releasing hormone signaling in female rats. Environ Health Perspect. 2009;117(5):757-762

50. Zalko D, Costagliola R, Dorio C, Rathahao E, Cravedi JP. In vivo metabolic fate of the xeno-estrogen 4-n-nonylphenol in Wistar rats. Drug Metab Dispos. 2003;31(2):168-178.

51. Ferguson SA, Flynn KM, Delclos KB, Newbold RR. Maternal and offspring toxicity but few sexually dimorphic behavioral alterations result from nonylphenol exposure. Neurotoxicol Teratol. 2000;22(4): $583-591$.
52. Latendresse JR, Newbold RR, Weis CC, Delclos KB. Polycystic kidney disease induced in $\mathrm{F}(1)$ Sprague-Dawley rats fed para-nonylphenol in a soy-free, casein-containing diet. Toxicol Sci. 2001;62(1):140-147.

53. Marsman D. NTP technical report on the toxicity studies of dibutyl phthalate (CAS No. 84-74-2) administered in feed to F344/N rats and B6C3F1 mice. Toxic Rep Ser. 1995;30:G1-G5.

54. Bindhumol V, Chitra KC, Mathur PP. Bisphenol A induces reactive oxygen species generation in the liver of male rats. Toxicology. 2003;188(2-3):117-124.

55. Nakagawa Y, Tayama S. Metabolism and cytotoxicity of bisphenol A and other bisphenols in isolated rat hepatocytes. Arch Toxicol. 2000; 74(2):99-105.

56. Lang IA, Galloway TS, ScarlettA, et al. Association of urinary bisphenolA concentration with medical disorders and laboratory abnormalities in adults. JAMA. 2008;300(11):1303-1310.

57. Calafat AM, Weuve J, Ye X, et al. Exposure to bisphenol A and other phenols in neonatal intensive care unit premature infants. Environ Health Perspect. 2009;117(4):639-644.

58. Howdeshell KL, Hotchkiss AK, Thayer JG. Environmental toxins: Exposure to bisphenol A advances puberty. Nature. 1999:763-764.

59. Krishnan AV, Stathis P, Permuth SF, Tokes L, Feldman D. Bisphenol-A: an estrogenic substance is released from polycarbonate flasks during autoclaving. Endocrinology. 1993;132(6):2279-2286.

60. Lee YM, Seong MJ, Lee JW, et al. Estrogen receptor independent neurotoxic mechanism of bisphenol A, an environmental estrogen. J Vet Sci. 2007;8(1):27-38.

61. Matsushima A, Kakuta Y, Teramoto T, et al. Structural evidence for endocrine disruptor bisphenol A binding to human nuclear receptor ERR gamma. J Biochem. 2007;142(4):517-524.

62. Gould JC, Leonard LS, Maness SC, et al. Bisphenol A interacts with the estrogen receptor alpha in a distinct manner from estradiol. Mol Cell Endocrinol. 1998;142(1-2):203-214.
Adolescent Health, Medicine and Therapeutics

\section{Publish your work in this journal}

Adolescent Health, Medicine and Therapeutics is an international, peer-reviewed, open access journal focusing on health, pathology, and treatment issues specific to the adolescent age group. All aspects of health maintenance, preventative measures and disease treatment interventions are addressed within the journal and practitioners from

\section{Dovepress}

all disciplines are invited to submit their work as well as healthcare researchers and patient support groups.. The manuscript management system is completely online and includes a very quick and fair peerreview system. Visit http://www.dovepress.com/testimonials.php to read real quotes from published authors. 